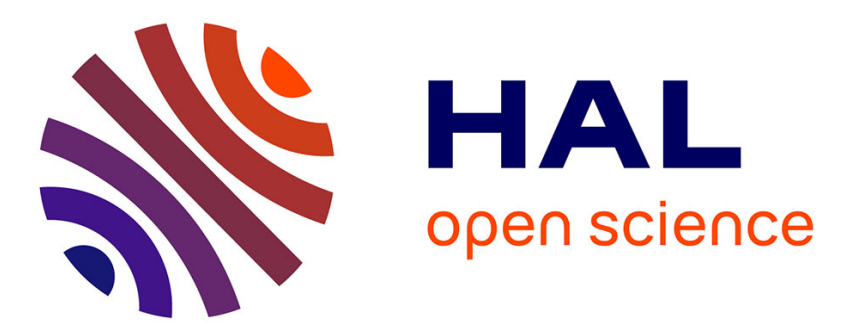

\title{
Analysis and expression of a cloned pre-T cell receptor gene
}

Claude Saint-Ruf, Katarina Ungewiss, Markus Groettrup, Ludovica Bruno, Hans Joerg Fehling, Harald von Boehmer

\section{- To cite this version:}

Claude Saint-Ruf, Katarina Ungewiss, Markus Groettrup, Ludovica Bruno, Hans Joerg Fehling, et al.. Analysis and expression of a cloned pre-T cell receptor gene. Science, 1994, 266 (5188), pp.1208-1212. 10.1126/science.7973703 . inserm-02177273

\section{HAL Id: inserm-02177273 https://www.hal.inserm.fr/inserm-02177273}

Submitted on 8 Jul 2019

HAL is a multi-disciplinary open access archive for the deposit and dissemination of scientific research documents, whether they are published or not. The documents may come from teaching and research institutions in France or abroad, or from public or private research centers.
L'archive ouverte pluridisciplinaire HAL, est destinée au dépôt et à la diffusion de documents scientifiques de niveau recherche, publiés ou non, émanant des établissements d'enseignement et de recherche français ou étrangers, des laboratoires publics ou privés. 
18. Russian Federation, statute 2667-1 (4 April 1992).

19. L. Grinberg, personal communication.

20. V. M. Popugaylo, R. P. Sukhanova, M. I. Kukhto, in Current Problems of Anthrax Prophylaxis in the USSR (Moscow, 1974), p. 50.

21. S. R. Hanna, G. A. Briggs, R. P. Hosker, Handbook on Atmospheric Diffusion (U.S. Department of Energy Report No. DOE/TIC-11223, Washington, DC, 1982).

22. D. E. Davids and A. R. Lejeune, Secondary Aerosol Hazard in the Field (Defence Research Establishment Suffield Report No. 321, Ralston, Alberta, Canada, 1981).

23. A. Birenzvige, Inhalation Hazard from Reaerosolized Biological Agents: A Review (U.S. Army Chemical Research, Development and Engineering Center Report No. TR-413, Aberdeen, MD, 1992).

24. P. S. Brachman, S. A. Plotkin, F. H. Bumford, M. M. Atchison, Am. J. Hyg. 72, 6 (1960).

25. D. W. Henderson, S. Peacock, F. C. Belton, J. Hyg. 54, 28 (1956); C. A. Gleiser, C. C. Berdjis, H. A. Hartman, W. S. Gochenour, Br. J. Exp. Pathol. 44, 416 (1963)

26. H. N. Glassman, Bacteriol. Rev. 30, 657 (1966).

27. A. V. El'kina, Zh. Mikrobiol. Epidemiol. Immunobiol. 1971 (no. 9), 112 (1971).
28. J. V. Jemski and G. B. Phillips, in Methods of Animal Experimentation, W. I. Gay, Ed. (Academic Press, New York, 1965), pp. 273-341.

29. A. C. Chamberlain, Proc. R. Soc. London A 296, 45 (1967).

30. T. W. Horst, in Atmospheric Sulfur Deposition, D. S. Shriner, C. R. Richmond, S. E. Lindberg, Eds. (Ann Arbor Science, Ann Arbor, Ml, 1980), pp. 275-283.

31. Å. Bovallius and P. Ånäs, in Proceedings of the 1st International Conference on Aerobiology, International Association for Aerobiology, Munich, West Germany, 13 to 15 August 1978, A. W. Frankland, E. Stix, H. Ziegler, Eds. (Erich Schmidt, Berlin, 1980), pp. 227-231.

32. G. A. Cristy and C. V. Chester, Emergency Protection Against Aerosols (Report No. ORNL-5519, Oak Ridge National Laboratory, Oak Ridge, TN, July 1981).

33. D. S. Ditmer and R. M. Grebe, Eds., Handbook of Respiration (Saunders, Philadelphia, 1958).

34. G. A. Young, M. R. Zelle, R. E. Lincoln, J. Infect. Dis. 79, 233 (1946).

35. J. V. Jemski, personal communication.

36. C. I. Bliss, Ann. Appl. Biol. 22, 134 (1935).

37. H. A. Druett, D. W. Henderson, L. Packman, S. J. Peacock, J. Hyg. 51, 359 (1953).
38. H. A. Druett, Nature 170, 288 (1952).

39. R. Scherrer and V. E. Shull, Can. J. Microbiol. 33 304 (1987)

40. We thank A. V. Yablokov, Counsellor to the President of Russia for Ecology and Health, for letters of introduction; Ural State University and its then rector, P. E. Suetin, for inviting us to Ekaterinburg; $S$. F. Borisov, V. A. Shchepetkin, and A. P. Tiutiunnik for assistance and advice; members of the Ekaterinburg medical community and the Sverdlovskaya Oblast Sanitary Epidemiological Service for discussions, notes, and documents; interview respondents for their cooperation; P. N. Burgasov, USSR Deputy Minister of Health at the time of the outbreak, for documents regarding livestock deaths; and People's Deputy L. P. Mishustina for the administrative list of those who died. I. V. Belaeva assisted with interviews. We also thank B. Ring, W. H. Bossert, P. J. M. Cannone, M. T. Collins, S. R. Hanna, J. V. Jemski, D. Joseph, H. F. Judson, M. M. Kaplan, J. Medema, C. R. Replogle, R. Stafford, J. H. Steele, and E. D. Sverdlov. Supported by grants to M.M. from the John D. and Catherine T. MacArthur Foundation and the Carnegie Corporation of New York. This article is dedicated to Alexander Langmuir.

\title{
Analysis and Expression of a Cloned Pre-T Cell Receptor Gene
}

\author{
Claude Saint-Ruf, ${ }^{*}$ Katharina Ungewiss, ${ }^{*}$ Marcus Groettrup, \\ Ludovica Bruno, Hans Joerg Fehling, Harald von Boehmer
}

The T cell antigen receptor (TCR) $\beta$ chain regulates early $T$ cell development in the absence of the TCR $\alpha$ chain. The developmentally controlled gene described here encodes the pre-TCR $\alpha(\mathrm{pT} \alpha)$ chain, which covalently associates with TCR $\beta$ and with the CD3 proteins forms a pre-TCR complex that transduces signals in immature thymocytes. Unlike the $\lambda 5$ pre-B cell receptor protein, the $p T \alpha$ chain is a type 1 transmembrane protein whose cytoplasmic tail contains two potential phosphorylation sites and a Src homology 3 (SH3)-domain binding sequence. Pre-TCR $\alpha$ transfection experiments indicated that surface expression of the pre-TCR is controlled by additional developmentally regulated proteins. Identification of the $\mathrm{pT} \alpha$ gene represents an essential step in the structure-function analysis of the pre-TCR complex.

T cell development takes place in discrete steps during which the TCR genes are rearranged and expressed in temporal order. During development of TCR $\alpha \beta$-expressing cells the TCR $\beta$ gene is rearranged and expressed before the TCR $\alpha$ gene $(1,2)$. Without TCR rearrangement the development of $T$ cells is arrested at an early stage (3-5). By introducing TCR $\beta$ transgenes into mice that are defective for rearrangement of antigen receptor genes, it was shown that TCR $\beta$ proteins, in the absence of TCR $\alpha$

C. Saint-Ruf is at the Unité INSERM 373 , Institut Necker, 75730 Paris, Cedex 15, France. K. Ungewiss, M. Groettrup, L. Bruno, H. J. Fehling, and H. von Boehmer are at the Basel Institute for Immunology, $\mathrm{CH}$ 4005 Basel, Switzerland.

*The first two authors contributed equally to this work. chains, are sufficient to promote early $\mathrm{T}$ cell development (6-8). Although such mice are still rearrangement-defective, their immature thymocytes (which express neither the CD4 nor CD8 proteins) begin to express CD4 and CD8 coreceptors, transcripts of the TCR $\alpha$ locus become detectable (7), and the number of thymocytes increases $(6-8)$. Introduction of TCR $\beta$ transgenes into normal mice suppresses rearrangement of endogenous TCR $\beta$ genes $(9,10)$. The TCR $\beta$ transgene is expressed on the cell surface in the absence of TCR $\alpha$ proteins in both normal (11) as well as in rearrangement-defective mice $(7,8,12)$ in an $80-\mathrm{kD}$ disulfied-linked complex and as a glycosyl-phosphatidylinositol (GPI)-linked 40-kD monomer.

The presence of the TCR $\beta$ chain in the
80-kD complex suggested that either the complex was a homodimer or that an unknown TCR chain was involved that may affect $T$ cell maturation. A glycosylated chain of $33 \mathrm{kD}$ (gp33) is paired with TCR $\beta$ proteins in a TCR $\beta$-transfected immature T cell line (SCB.29) from severe combined immunodeficient (SCID) mice (12), but could not be identified in normal thymocytes $(12,13)$. The gp33-TCR $\beta$ complex of SCB.29 cells is associated with CD3 proteins $(8,12)$ and cross-linking of TCR chains initiates $\mathrm{Ca}^{2+}$ mobilization. This suggested that this TCR $\beta$ complex could be responsible for the developmental progression observed in TCR $\beta$ transgenic, rearrangement-deficient mice, whereas the TCR $\beta$ GPI-linked monomer could represent a transgenic artifact $(14,15)$. We have now cloned the gene encoding gp33 and examined its structure and expression. Because of its properties, the gp33 protein was named the pre-TCR $\alpha(\mathrm{pT} \alpha)$ chain.

Pre-T cell receptor $\alpha$ (pT $\alpha$ ) expression in immature $\mathrm{T}$ cells. The $\mathrm{pT} \alpha$ chain can be identified by two-dimensional (diagonal) gel electrophoresis, in which the disulfidelinked $\mathrm{pT} \alpha$ protein under reducing conditions migrates away from the diagonal just underneath the TCR $\beta$ protein (12) (Figs. 1 and 2). The analytical method was scaled up to obtain sufficient amounts of $\mathrm{pT} \alpha$ protein for microsequencing. In a first attempt a 20 -amino-acid-long $\mathrm{NH}_{2}$-terminal sequence was obtained; a peptide of the 18 $\mathrm{NH}_{2}$-terminal residues was synthesized and injected into rabbits to obtain a pT $\alpha$-specific antiserum. The antiserum was tested for binding to the $\mathrm{pT} \alpha$ protein. To this end lysates from the TCR $\alpha$-negative SCB.29 cell line as well as the TCR $\alpha \beta$-expressing B6.2.16BW hybridoma (12) were precipitated with the monoclonal antibody (mAb) F23.1 to $\mathrm{V}_{\beta} 8$ proteins (16). Precipitates 
Fig. 1. Identification of the pT $\alpha$ chain by antibodies. Immunoprecipitations of TCR $\beta$ from either SCB.29 or B6.2.16BW cells were immunoblotted with control reagents or antibodies to TCR $\beta$ or $\mathrm{pT} \alpha$, with or without peptide (PEP) from the $\mathrm{NH}_{2}$-terminus of $\mathrm{pT} \alpha$ (38). SCB.29, cell line from SCID mouse transfected with TCR $\beta$; B6.2.16BW, TCR $\alpha \beta$ expressing T cell hybridoma; GantiR-HRPO, goat antibodies to rabbit immunoglobulin conjugated to horseradish peroxidase; F23.1, $\mathrm{mAb}$ to TCR $\beta\left(\mathrm{V}_{\beta} 8\right)$; $\mathrm{PI53}$, pre-immune serum from rabbit 53; S53, immune serum from rabbit 53 injected with $\mathrm{NH}_{2}$-terminal peptide of pT $\alpha$; CP53, affinity column-purified S53. Molecular sizes are given in kilodaltons.
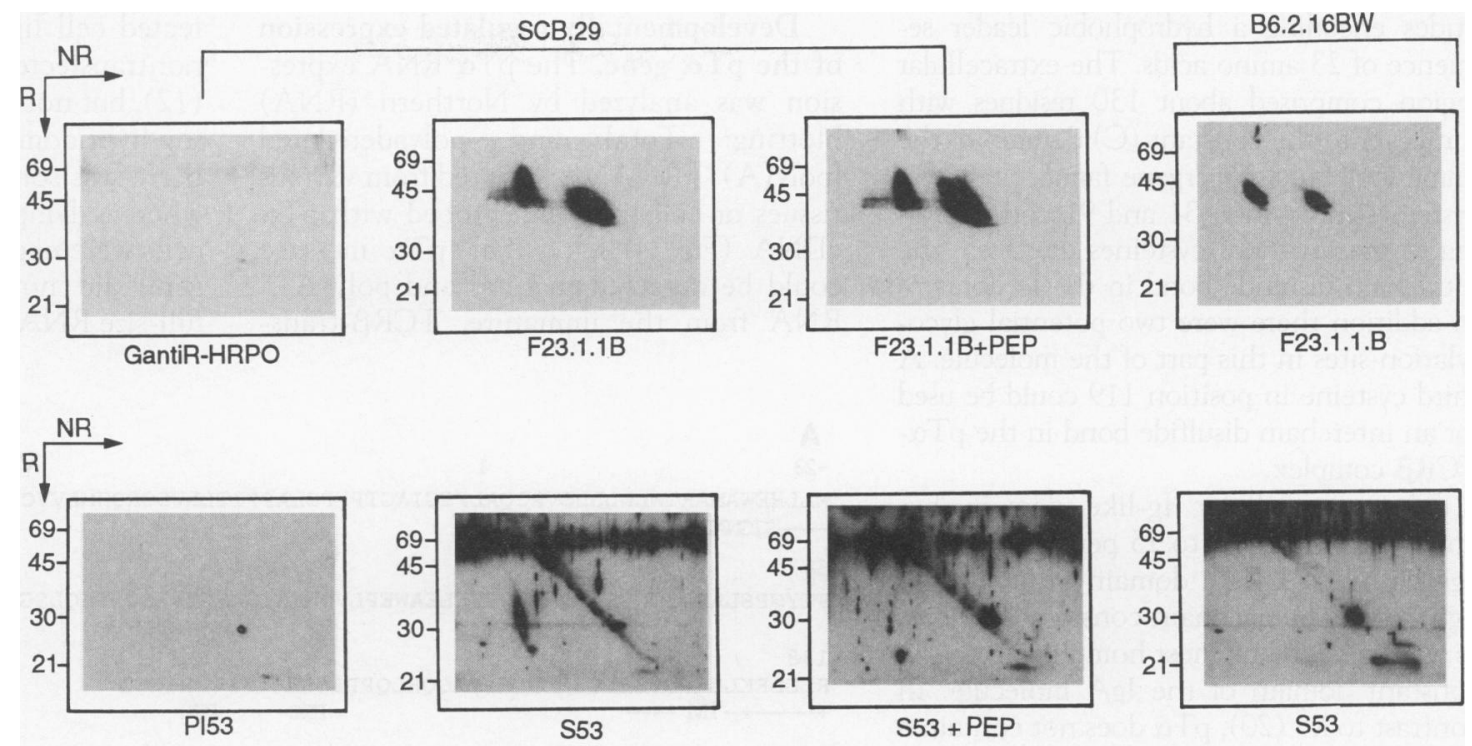

were separated on diagonal gels and the proteins analyzed in Western immunoblots by staining with either mAb F23.1 or serum from immunized rabbit 53 (Fig. 1). The TCR $\beta \mathrm{mAb}$ stained proteins off and on the diagonal, corresponding to disulfide-linked and -unlinked TCR $\beta$ proteins, respectively, in the lysates of both SCB.29 and B6.2.16.BW cells (Fig. 1, top) whereas the control GantiR-HRPO [goat anti-rabbit immunoglobulin (Ig) conjugated to horseradish peroxidase] produced no signal. The pre-immune serum from rabbit 53 (PI53) likewise produced no signal (except for some weak reactivity with the $30-\mathrm{kD}$ marker on the diagonal) whereas the immune serum (S53) stained in SCB.29 lysates a protein off the diagonal beneath the TCR $\beta$ protein that was not stained in B6.2.16BW lysates (Fig. 1, middle). The staining of the $\mathrm{pT} \alpha$ protein could be completely inhibited by the specific peptide, whereas the extensive background staining could not. Affinity purification on a peptide column finally yielded a reagent of exquisite specificity for the $\mathrm{pT} \alpha$ protein that became visible as a streak of differentially glycosylated proteins as well as a nonglycosylated dot (Fig. 1, bottom). These results established that the protein sequence was obtained from the $\mathrm{pT} \alpha$ protein and that the antiserum could be used to analyze expression of the pT $\alpha$ TCR $\beta$ complex in various cells.

Because the pT $\alpha$-TCR $\beta$ complex in thy- mocytes was not previously identified, we used the above approach to examine this complex in thymocytes from TCR $\alpha$-deficient (TCR $\alpha^{-l-}$ ) mice (Fig. 2). We could detect the pT $\alpha$-TCR $\beta$ complex by precipitation with the mAb $\mathrm{H} 57$ to all TCR $\beta$ proteins (17) from lysates of TCR $\alpha^{-l-}$ thymocytes. Thus the pT $\alpha$-TCR $\beta$ complex does not represent a peculiarity of a single cell line, but is also formed and glycosylated in immature thymocytes.

Cloning of the pT $\alpha$ chain complementary DNA (cDNA). To obtain a pT $\alpha$ chain cDNA sequence we prepared a cDNA library from the SCB.29 cell line in lambda ZAP II (Stratagene). A lysate of the library was prepared and amplified by PCR (polymerase chain reaction) with degenerate or nondegenerate oligonucleotides, corresponding to the most $3^{\prime}$ part of the pT $\alpha \mathrm{NH}_{2}$ - terminal protein sequence and an oligonucleotide complementary to the lambda ZAP vector-sequence at the $5^{\prime}$ end of the cDNA inserts. Specific PCR products were identified by Southern (DNA) hybridization with another set of degenerate oligonucleotides corresponding to the $\mathrm{pT} \alpha$ sequence between the PCR primers. Hybridizing PCR fragments were subcloned and sequenced. In this way a fragment of approximately $180 \mathrm{bp}$ was obtained that encoded part of the $5^{\prime}$ untranslated region, the leader sequence, and the sequence corresponding to the first five amino acids of the $\mathrm{pT} \alpha$ protein. This fragment was then used as a probe for conventional screening of the SCB. 29 cDNA library. Several independent lambda clones were isolated that contained the full-length coding sequence of $\mathrm{pT} \alpha$. The sequence revealed an open reading frame of 618 nucle-
Fig. 2. Identification of the pT $\alpha$ chain in TCR $\alpha^{-1-}$ thymocytes $(4 \times$ $10^{9}$ cells $)$ and SCB.29 $\left(2 \times 10^{7}\right.$ cells). Two-dimensional SDSPAGE of immunoprecipitates with $\mathrm{H} 57$ (17). The $\mathrm{pT} \alpha$ chain is revealed by CP53 serum. The spot on the diagonal may represent nondisulfide-linked $\mathrm{pT} \alpha$ in the precipitate. Staining with mAb F23.1 was similar to that in Fig. 1. Methods were as in Fig. 1. Molecular sizes are indicated in kilodaltons.
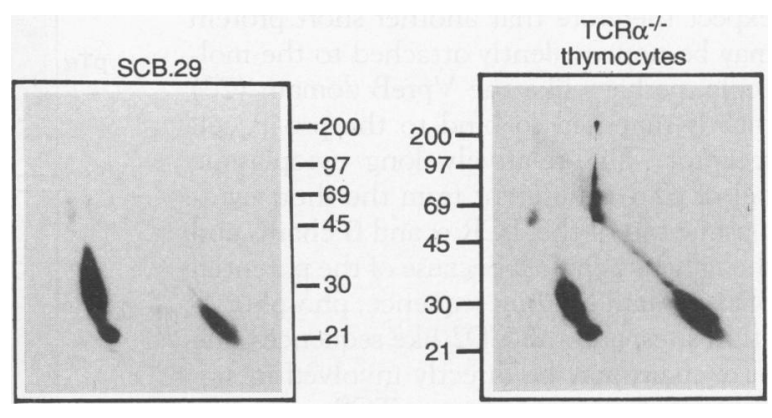
otides encoding a hydrophobic leader sequence of 23 amino acids. The extracellular region comprised about 130 residues with similarity to the constant $(C)$ domain of the immunoglobulin supergene family with two cysteines in position 31 and 91 corresponding to the invariant cysteines that form the intrachain disulfide bond in the Ig domain. In addition there were two potential glycosylation sites in this part of the molecule. A third cysteine in position 119 could be used for an interchain disulfide bond in the $\mathrm{pT} \alpha$ TCR $\beta$ complex.

The extracellular Ig-like domain has only some weak (20 to 25 percent) homology with the Ig-like domain of $\operatorname{TCR} \alpha$, Ig light and Ig heavy chain constant domains, as well as $\lambda 5$, being most homologous to the constant domain of the IgA molecule. In contrast to $\lambda 5$ (20), pT $\alpha$ does not contain a J-like sequence but strictly ends at the Iglike $\mathrm{C}$ domain. Unlike $\lambda 5$, the $\mathrm{pT} \alpha$ protein contains a transmembrane region and a cytoplasmic tail. The transmembrane region of about 20 hydrophobic residues includes two basic amino acids (arginine and lysine) that are identical to the polar residues in the transmembrane part of the TCR $\alpha$ chain and are separated by the same number of hydrophobic residues (18). In the TCR $\alpha$ chain, these polar residues are essential for the assembly and transport of the TCR $\alpha \beta$ CD3 complex (18). The cytoplasmic region of about 31 residues is rich in proline residues and could constitute a SH3-domain binding region. In addition, there are PPSRK and PPTHR sequences similar to the PPGHR motif present in the cytoplasmic tail of CD2, known to be involved in CD2-dependent $T$ cell activation (19) and containing two potential phosphorylation sites for protein kinase C (Fig. 3).

The sequence analysis indicates that the $\mathrm{pT} \alpha$ protein is well suited for pairing with the TCR $\beta$ chain. Even though there is only moderate identity to any particular member of the Ig supergene family, this protein bears the hallmarks of this family. The cysteine in position 119 as well as the transmembrane part seem designed to form a complex with TCR $\beta$ and CD 3 proteins. The pT $\alpha$-TCR $\beta$ heterodimer has an asymmetrical shape because the TCR $\beta$ has two and the $\mathrm{pT} \alpha$ only one extracellular Ig-like domain. One might expect therefore that another short protein may be noncovalently attached to the molecule, perhaps like the VpreB domain (20) that is supposed to bind to the pre-B cell receptor. The relatively long cytoplasmic tail of $\mathrm{pT} \alpha$ is different from the short cytoplasmic tail of the TCR $\alpha$ and $\beta$ chains and the Ig heavy chains. Because of the potential $\mathrm{SH} 3$-domain binding sequence, phosphorylation sites, and the CD2 like sequences, the $\mathrm{pT} \alpha$ chain may be directly involved in signal transduction by the pre-TCR.
Developmentally regulated expression of the pT $\alpha$ gene. The pT $\alpha$ RNA expression was analyzed by Northern (RNA) blotting: Total and polyadenylated $\left[\operatorname{poly}(\mathrm{A})^{+}\right]$RNA was isolated from various tissues or cell lines and probed with $\mathrm{pT} \alpha$ cDNA (Fig. 4, left). The pT $\alpha$ message could be detected in total and poly $(\mathrm{A})^{+}$ RNA from the immature, TCR $\beta$-trans- fected cell line SCB.29 as well as in the nontransfected parental line SCI.ET.27F (12), but not at all in the TCR $\alpha \beta$-expressing hybridoma B6.2.16.BW (12). In mice, there was some expression in the thymus, whereas lymph node (Fig. 4) and spleen cells were negative. Expression of the pT $\alpha$ gene did not require rearrangement, as full-size RNA was abundant in the thymus

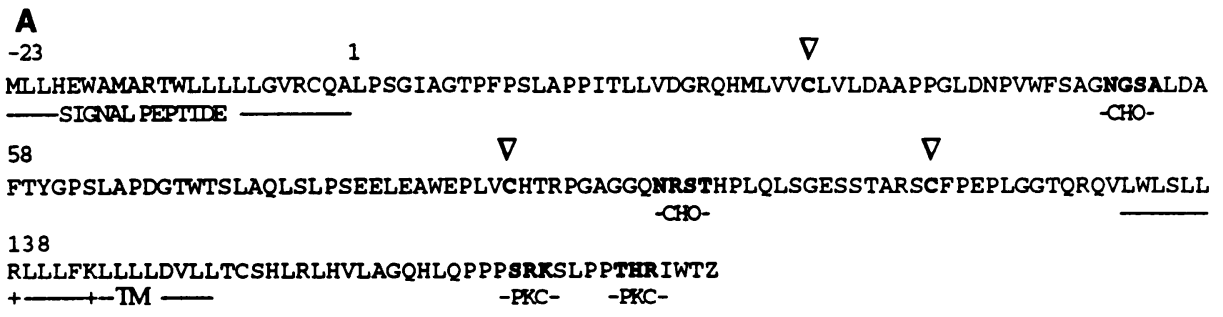

Fig. 3. (A) Predicted $p T \alpha$ sequence. Amino acid sequence of the open reading frame of $p T \alpha$ cDNA. The nucleotide sequence is available from the GenBank database, accession number U16958. Amino acid numbering is given at the left. Locations of the potential $\mathrm{N}$-linked glycosylation sites $(\mathrm{CHO})$, the predicted leader (peptide signal) and transmembrane (TM) sequences, and the potential protein kinase $C$ phosphorylation sites (PKC) are shown. The sequences PPSRK (169) and PPTHR (176) are similar to the PPGHR motif found in CD2. The three cysteines in positions 31 , 91 , and 119 are marked $(\nabla)$. DNA sequence analysis was done with the GCG program (Genetics computer group, program manual for the GCG package, version 7, April 1991). Homology searches in the EMBL (release 33.0, March 1994), GenBank (release 83.0, February 1994) and SWISSPROT (release 28.0, February 1994) data banks were done with the FASTA (39) program. Sequence comparisons and alignments with immunoglobulin superfamily domains were done

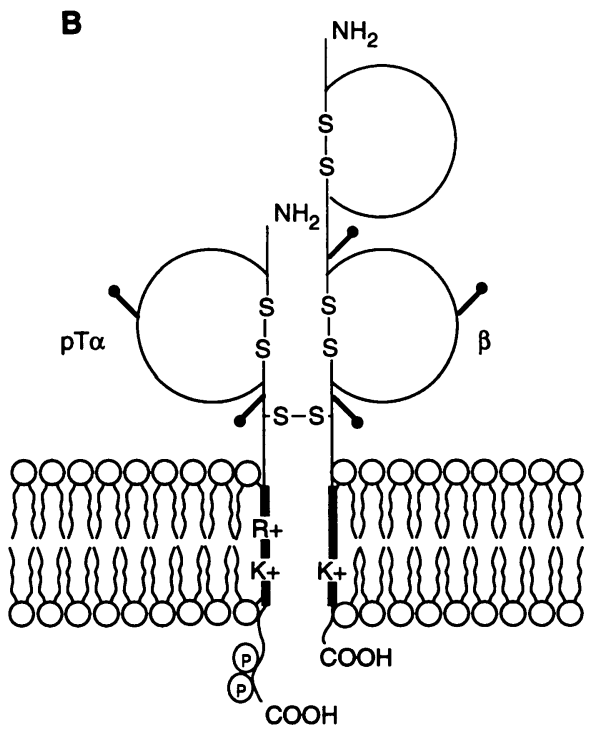
with the PILEUP (40) program. Single-letter abbreviations for the amino acid residues are: A, Ala; C, Cys; D, Asp; E, Glu; F, Phe; G, Gly; H, His; I, lle; K, Lys; L, Leu; M, Met; N, Asn; P, Pro; Q, Gln; R, Arg; S, Ser; $\mathrm{T}$, Thr; V, Val; W, Trp; and Y, Tyr. (B) The pT $\alpha$-TCR $\beta$ complex. - Corresponds to the N-linked glycosylation sites. $\mathrm{P}$, represents protein kinase $\mathrm{C}$ phosphorylation sites in the $\mathrm{pT} \alpha$ cytoplasmic tail. Two basic amino acids, arginine $\left(\mathrm{R}^{+}\right)$and lysine $\left(\mathrm{K}^{+}\right)$, are located in the pT $\alpha$ transmembrane region.

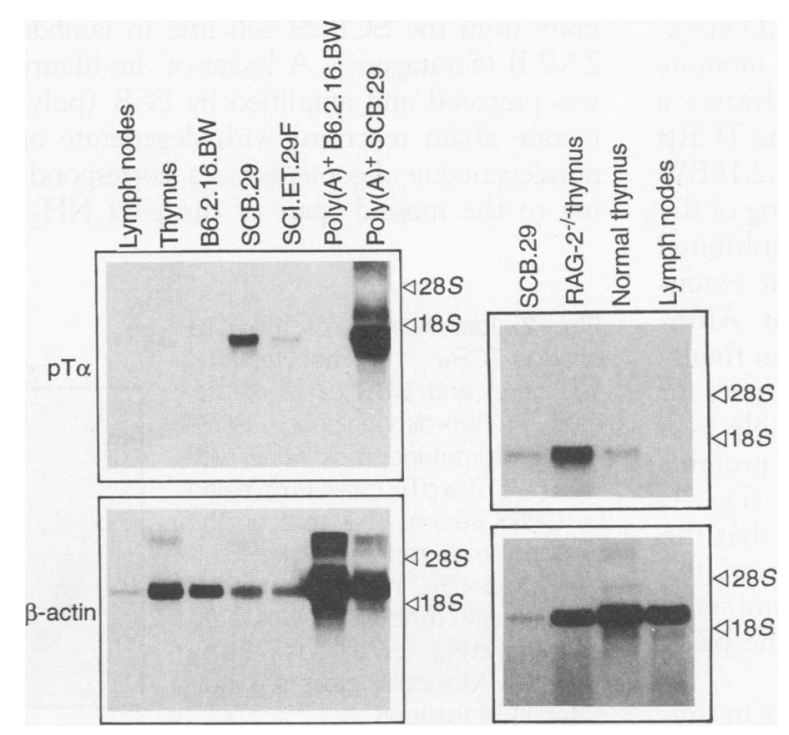

Fig. 4. pT $\alpha$ mRNA expression in various cells and tissues. Total or poly $(A)^{+}$RNA was isolated from cell lines and tissues and the RNA was separated on agarose gels. After transfer, the RNA was probed with a labeled cDNA specific for $p T \alpha$; after the original probe was stripped from the filter, it was again hybridized with a labeled $\beta$-actin probe (41). 
of RAG-2-1- (recombination activating gene 2) rearrangement-defective mice (21) and it was expressed higher in RAG$2^{-1-}$ thymocytes than in thymocytes from normal mice (Fig. 4). The latter result suggested that the $\mathrm{pT} \alpha$ gene was predominantly expressed in the more immature thymocytes.

Expression in early thymocytes was confirmed by PCR analysis with oligonucleotides specific for the pT $\alpha$ gene (Fig. 5). The developmentally regulated $\mathrm{pT} \alpha$ message was expressed in different amounts at successive stages of thymic development. There was high expression in $\mathrm{CD}_{4}{ }^{-} \mathrm{CD} 25^{+}$and $\mathrm{CD} 44^{-} \mathrm{CD} 25^{-}$ double negative $\left(\mathrm{CD}^{-} \mathrm{CD}^{-}\right)$cells but there was weaker expression in earlier and later stages of development. Small single positive (expressing only CD4 or CD8) thymocytes had no detectable pT $\alpha$ RNA. The difference in the intensity of the pT $\alpha$ RNA bands between RAG-2 ${ }^{-1-}$ and normal thymocytes in Fig. 4 is explained by the fact that most cells in the normal thymus are small $\mathrm{CD}^{+}{ }^{+} \mathrm{CD} 8{ }^{+}$cells, whereas in the RAG-2-1- thymus most cells are $\mathrm{CD}_{44^{-}} \mathrm{CD} 25^{+}$and because $\mathrm{CD} 44^{-} \mathrm{CD}^{+} 5^{+}$cells express more $\mathrm{pT} \alpha$ RNA than small $\mathrm{CD} 4^{+} \mathrm{CD} 8^{+}$thymocytes.

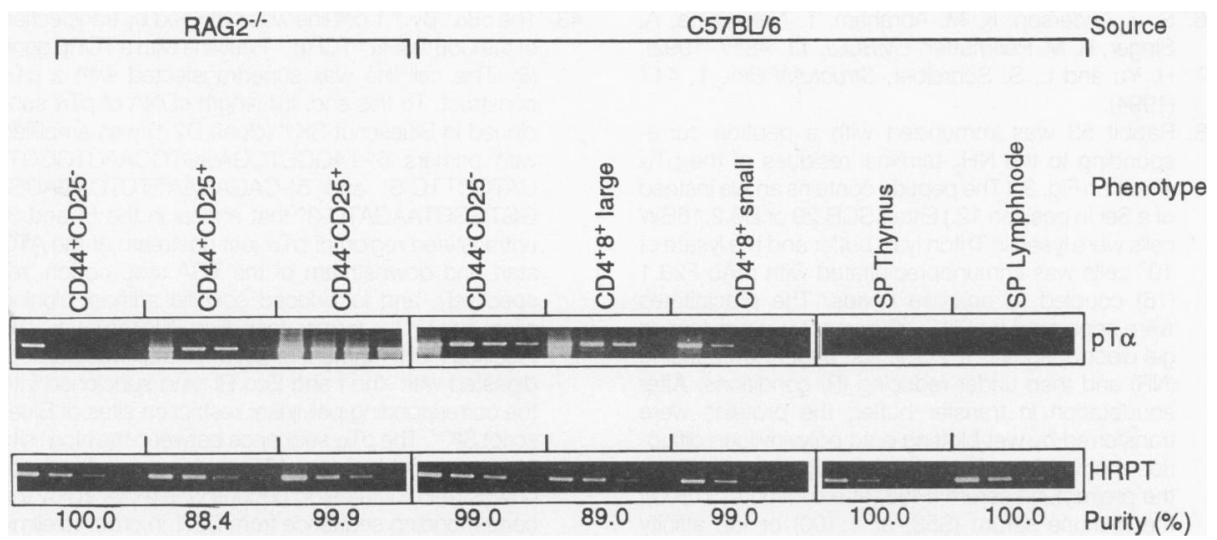

Fig. 5. Semiquantitative analysis of $\mathrm{pT} \alpha$ expression on lymphocyte subsets. Thymocytes from RAG-2 ${ }^{-1-}$ and normal C57BL/6 mice were separated by fluorescence-activated cell sorting (FACS) or complementdependent killing. Subsets of T cells were subjected to polymer chain reaction (PCR) as described in (42). Samples were stained with ethidium bromide. SP, single positive (CD4 or CD8) T cells; HPRT, hypoxanthine-guanine phosphoribosyl transferase.

Fig. 6. Transfection of a pT $\alpha$ construct into a mature, TCR $\alpha$-deficient T cell line. Immunoprecipitations of TCR $\beta$ from SCB.29, SCI.ET.27F (the nontransfected SCID cell line), the pT $\alpha$ transfectants of $58 \alpha^{-} \beta$ y. 1 (a TCR $\alpha$-mature T cell line) (43) named $58 \alpha^{-} \beta$ y. $1-33$ and represented by clones 7,9 , and 10 , and $58 \alpha^{-}-\beta y .1$ cells were separated under nonreducing (NR) and reducing (R) conditions and immunoblotted with the CP33 pT $\alpha$ antiserum.

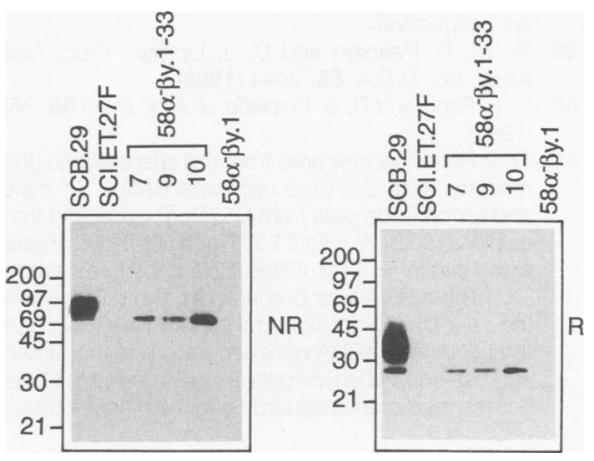

chains. When these cells were supertransfected with the pT $\alpha$ construct, intracellular $\mathrm{pT} \alpha$-TCR $\beta$ dimers were observed, but in contrast to dimers in the immature $T$ cell line SCB.29, the disulfide-linked pT $\alpha$ proteins in the mature $T$ cell line were poorly or not at all glycosylated, indicating that most of the heterodimer did not leave the endoplasmic reticulum (Fig. 6). Also, surface expression of TCR $\beta$ in the $\mathrm{pT} \alpha$ transfectants was not increased, whereas TCR $\alpha \beta$ surface expression was observed after TCR $\alpha$ transfection. This result was consistent with the hypothesis that another developmentally regulated protein (VpreT) may be required for proper assembly, glycosylation, and transport to the cell surface of the pT $\alpha$-TCR $\beta$ complex. The result is of course equally consistent with the hypothesis that mature $T$ cells may contain proteins that prevent pT $\alpha$-TCR $\beta$ complexes from leaving the endoplasmic reticulum and that the pT $\alpha$ TCR $\beta$ complex can only be transported to the cell surface in the absence of these retention molecules.

Regulation of $\mathrm{T}$ cell development by the pre-TCR complex. In conjunction with experiments in TCR $\beta$ transgenic, rearrangement-defective SCID mice $(6-8)$ and analogous experiments in TCR $\beta$ transgenic $\mathrm{RAG}^{-1-}$ mice $(21,24)$, our results are consistent with the hypothesis that the preTCR complex is sufficient to promote $T$ cell development in the absence of other TCR chains encoded by rearranging genes. Although the experiments in the TCR $\beta$ transgenic, rearrangement-deficient mice have indicated that TCR $\beta$ proteins are sufficient to induce $T$ cell maturation, studies in TCR $\beta^{-1-}$ mice suggest that a TCR $\beta$ protein is not essential for the expression of CD4 and CD8 molecules in development because $\mathrm{CD}^{+} \mathrm{CD} 8^{+}$cells are present in $\mathrm{TCR}^{-1-}$ mice (24). The possibility was considered that $\mathrm{CD}^{+}{ }^{+} \mathrm{CD} 8^{+}$thymocytes in TCR $\beta^{-1-}$ mice were of the $\gamma \delta$ lineage (because they were absent in TCR $\beta^{-1-}$ $\mathrm{TCR} \gamma^{-1-}$ mice) and that the TCR $\beta$ protein was essential for expression of CD4 or CD8 coreceptors in the $\alpha \beta$ lineage (24). There are, however, no experiments supporting this view. In contrast, reconstitution of thymuses from $\operatorname{SCID}(25,26)$ or $\mathrm{RAG}^{-1-}$ mice (22) with either pro-T cells or $\gamma \delta \mathrm{T}$ cells have shown that thymocytes devoid of TCR proteins can express CD4 and CD8 molecules as long as other TCR-bearing cells are present. Thus the pre-TCR complex may not directly regulate CD4 and CD8 expression through intracellular signaling.

Intracellular signaling by the pre-TCR complex may, however, be essential to obtain large numbers of immature thymocytes. This can be deduced from experiments that showed that the proportion of productive 
rearrangements in $\mathrm{CD}_{4} 4^{-} \mathrm{CD} 25^{-}(28)$ and total thymocytes (29) from TCR $\alpha^{-/-}$mice were much higher than expected if cells of this phenotype could similarly expand, irrespective of whether or not they carried productive TCR $\beta$ genes. Thus the pre-TCR complex may regulate survival and expansion of immature $\mathrm{T}$ cells rather than regulating directly CD4 and CD8 gene expression in the lineage of $\alpha \beta \mathrm{T}$ cells.

The role of the pre-TCR complex in T cell development is supported by other studies. In SCID (30) as well as in TCR $\beta$ or RAG-deficient $(31,32)$ mice, the effects of productive TCR $\beta$ transgenes on thymocyte development can be mimicked by treating thymocytes of these mice with antibodies to CD3ع. These results support the hypothesis that the TCR $\beta$ protein exerts its function through a pre-TCR complex that associates with CD3 proteins. It is not clear from these studies whether signaling through $\mathrm{CD} 3$ is all that is required or whether the cytoplasmic part of the pT $\alpha$ chain plays an essential role. A potential role of the cytoplasmic tail of pT $\alpha$ needs to be analyzed under more physiological conditions.

A role of $\mathrm{p} 56^{\text {lck }}$ in the signaling by the pre-TCR is implicated by studies in mice that are Lck-defective (33) or carry a dominant negative Lck mutation (34). The Lck dominant negative mutation results in a developmental arrest that resembles that of rearrangement-deficient mice. On the other hand the introduction of an active lck gene in rearrangement-deficient mice (35) or in normal mice (36) causes the same effects as a TCR $\beta$ transgene. Thus $\mathrm{p} 56^{\text {lkk }}$ may be part of the signaling cascade of the pre-TCR complex. Because the cytoplasmic tail of the pT $\alpha$ chain contains a proline-rich, potential SH3-binding domain (37), p56 $6^{\text {lk }}$ may be recruited by the $\mathrm{pT} \alpha$ protein into the pre-TCR complex.

The cloning and expression analysis of the pT $\alpha$ gene has established that the preTCR is expressed in immature thymocytes and opens the way to determine the precise structure and function of the pre-TCR complex in $\mathrm{T}$ cell development.

\section{REFERENCES AND NOTES}

1. D. H. Raulet, R. D. Garman, H. Saito, S. Tonegawa, Nature 314, 101 (1985).

2. R. H. Snodgrass, Z. Dembic, M. Steinmetz, $H$. von Boehmer, ibid. 315, 232 (1985)

3. M. Bosma and A. M. Carrol, Annu. Rev. Immunol. 9, 323 (1991)

4. Y. Shinkai, Cell 68, 855 (1992).

5. P. Mombaerts et al., ibid., p. 869.

6. H. von Boehmer, Annu. Rev. Immunol. 8, 531 (1990).

7. H. Kishi et al., EMBO J. 10, 93 (1991).

8. M. Groettrup, A. Baron, G. Griffiths, R. Palacios, H. von Boehmer, ibid. 11, 2735 (1992).

9. Y. Uematsu et al., Cell 52, 831 (1988)

10. R. G. Fenton, P. Marrack, J. W. Kappler, O. Kana- gawa, J. G. Seidman, Science 241, 1089 (1988)

11. H. von Boehmer et al., Proc. Natl. Acad. Sci. U.S.A. 85, 9729 (1988).

12. M. Groettrup et al., Cell 75, 283 (1993)

13. M. Groettrup and H. von Boehmer, Eur. J. Immunol. 23, 1393 (1993)

14. H. von Boehmer, Cell 76, 219 (1994)

15. M. Groettrup and $\mathrm{H}$. von Boehmer, Immunol. Today 14, 6101 (1993)

16. U. D. Staerz, H.-G. Rammensee, J. D. Benedetto, M. J. Bevan, J. Immunol. 134, 3994 (1985)

17. R. T. Kubo, W. Born, J. Kappler, P. Marrack, M. J. Pigeon, ibid. 142, 2736 (1989).

18. P. Cosson, S. P. Lankford, J. S. Bonifacio, R. D. Klausner, Nature 351, 414 (1991)

19. H. C. Chang, J. Exp. Med. 172, 351 (1990)

20. H. Karasuyama, A. Kudo, F. Melchers, ibid., p. 969.

21. Y. Shinkai et al., Science 259, 822 (1993).

22. M. Groettrup, thesis, University of Basel, Switzerland (1993)

23. A. Kudo and F. Melchers, EMBO J. 6, 2267 (1987).

24. P. Mombaerts et al., Nature 360, 225 (1992).

25. E. W. Shores, S. O. Sharrow, A. Singer, Eur. J. Immunol. 21, 973 (1991).

26. F. Lynch and E. M. Shevach, Int. Immunol. 5, 991 (1993).

27. H. R. Rodewald, unpublished data.

28. E. C. Dudley, H. T. Petrie, L. M. Shah, M. J. Owen, A. C. Hayday, Immunity 1, 83 (1994)

29. C. A. Mallick, E. C. Dudley, J. L. Viney, M. J. Owen, A. C. Hayday, Cell 73, 513 (1993)

30. C. N. Levelt, A. Ehrfeld, K. Eichmann, J. Exp. Med. 177, 707 (1993)

31. C. N. Levelt, P. Mombaerts, A. Iglesias, S. Tonegawa, K. Eichmann, Proc. Natl. Acad. Sci. U.S.A. 90, 11401 (1993)

32. H. Jacobs et al., Eur. J. Immunol. 24, 934 (1994).

33. T. J. Molina et al., Nature 357, 161 (1992).

34. S. D. Levin, S. J. Anderson, K. A. Forbush, R. M. Perlmutter, EMBO J. 12, 1671 (1993)

35. P. Mombaerts, S. J. Anderson, R. M. Perlmutter, T. W. Mak, S. Tonegawa, Immunity 1, 261 (1994).

36. S. J. Anderson, K. M. Abraham, T. Nakayama, A Singer, R. M. Perlmutter, EMBO J. 11, 4877 (1992)

37. H. Yu and L. S. Schreiber, Structural Biol. 1, 417 (1994).

38. Rabbit 53 was immunized with a peptide corresponding to the $\mathrm{NH}_{2}$-terminal residues of the pTa shown in Fig. 3. (The peptide contains an Ala instead of a Ser in position 12.) Either SCB.29 or B6.2.16BW cells were lysed in Triton lysis buffer and the lysate of $10^{7}$ cells was immunoprecipitated with mAb F23.1 (16) coupled to agarose beads. The precipitates were separated by SDS-10 percent polyacrylamide gel electrophoresis (PAGE), first under nonreducing (NR) and then under reducing (R) conditions. After equilibration in transfer buffer, the proteins were transferred by wet blotting onto polyvinyliden difluoride membranes. Filters were incubated with eithe the preimmune serum (PI53, at a dilution of $1: 100$ ) the immune serum $(\mathrm{S} 53$, at $1: 100)$ or the affinity column-purified (CP53, at 1:100) in phosphate-buffered saline containing 0.4 percent Tween and 2 percent fetal calf serum. For peptide competition, peptide $(35 \mu \mathrm{g} / \mathrm{ml})$ was first incubated with $\mathrm{S} 53$ serum or mAb F23.1 for 1 hour. For detection of TCR $\beta$ protein a F23.1-biotin conjugate was used. After the firststage reagents were removed, GantiR-HRPO at $1: 20,000$ or streptavidine-HRPO $(1: 5000)$ was added for visualization of the rabbit and F23.1 antibodies, respectively.

39. W. M. R. Pearson and D. J. Lipman, Proc. Nat/. Acad. Sci. U.S.A. 85, 2444 (1988)

40. D. F. Feng and R. S. Doolittle, J. Mol. Evol. 35, 359 (1987)

41. Total RNA was prepared from cell suspensions (thymocytes from C57BL/6 mice and RAG-2 ${ }^{-1-}$ mice, and lymph node cells from C57BL/6 mice) and from cell lines (SCB.29, SCI.ET.27F and B6.216.BW cells) with RNAzol B (TM Cinna Scientific, Friedswood TX). The mRNA was prepared from total RNA with the use of the Oligotex TM mRNA Kit (QIAGEN). Both total RNA and mRNA were separated on 1.2 percent agarose-formaldehyde gels and transferred to GeneScreen membranes according to the manufacturer's recommendations (Du Pont). Filters were first hybridized at $65^{\circ} \mathrm{C}$ for 8 hours and hybridized with the same solution [1 mM EDTA, $0.5 \mathrm{M} \mathrm{NaH}_{2} \mathrm{PO}_{4}, 7$ percent SDS, and salmon sperm DNA $(100 \mu \mathrm{g} / \mathrm{ml})]$ containing the specific probe at $65^{\circ} \mathrm{C}$ overnight. To remove any unspecifically bound probe, the membranes were washed first with $1 \mathrm{mM}$ EDTA, $40 \mathrm{mM} \mathrm{NaH}_{2} \mathrm{PO}_{4}$, percent SDS at $65^{\circ} \mathrm{C}$. Filters were hybridized first with a cDNA probe corresponding to the entire coding sequence of pT $\alpha$ and subsequently, after dishybridization, with a probe specific for $\beta$-actin message. Washed membranes were exposed to Kodak $X$-OMAT AR film at $-70^{\circ} \mathrm{C}$ for 1 to 5 days.

42. $\mathrm{CD}_{4} 4^{+} \mathrm{CD} 25^{-}, \mathrm{CD} 44^{+} \mathrm{CD} 25^{+}$, and $\mathrm{CD} 44^{-} \mathrm{CD} 25^{+}$ double-negative (CD4- $\left.{ }^{-} \mathrm{CD}^{-}\right)$thymocytes were obtained from RAG-2 ${ }^{-1-}$ mice. CD44-CD25- thymocytes were obtained from C57BL/6 mice by complement-dependent killing of thymocytes with antibodies to CD4 and CD8. The thymocytes were then stained with antibodies specific for CD4, CD8, CD44, CD25, and CD3 surface markers to obtain the desired populations by cell sorting. The purity of the subsets was deduced from reanalysis of sorted cells. In order to quantitate $\mathrm{pT} \alpha \mathrm{RNA}$, cells $\left(5 \times 10^{4}\right)$ were directly sorted in $500 \mu$ l of RNAzol (TM Cinna Scientific), and total RNA was extracted according to the manufacturer's protocol. The cDNA was prepared with random hexamer primers and reverse-transcribed with Superscript kit (Gibco BRL). Dilutions $(1: 3)$ of CDNA in water were then used in PCR amplification reactions. Primers used were oligonucleotides recognizing sequences in the $5^{\prime}$ and $3^{\prime}$ regions of the pT $\alpha$ (5'-CTGCAACTGGGTCATGCTTC- $3^{\prime}$ and 5' TCAGACGGGTGGGTAAGATC$\left.3^{\prime}\right)$ and HRPT (5'-CACAGGACTAGAACACCTGC-3' and 5'-GCTGGTGAAAAGGACCTCT-3') genes. Amplification was done for 35 cycles at an annealing temperature of $55^{\circ} \mathrm{C}$ with a thermal cycling machine (Perkin-Elmer Cetus). A 15- $\mu$ l portion of each amplified product was separated through a $1.2 \%$ agarose gel by electrophoresis and stained with ethidium bromide.

43. The $58 \alpha^{-} \beta y .1 T$ cell line was obtained by transfection of the C58 TCR $\alpha-$ TCR $\beta-$ T cell line with a TCR $\beta$ gene (8). This cell line was supertransfected with a pTa construct. To this end, full-length cDNA of pT $\alpha$ subcloned in Bluescript SK+ (clone D2.1) was amplified with primers 5'-TAGCCTCGAGCTGCAACTGGGTCATGCTTC-3' and 5'-CAGAGAATTCTCAGACGGGTGGGTAAGATC- $3^{\prime}$ that anneal in the $5^{\prime}$ and $3^{\prime}$ untranslated region of pT $\alpha$ just upstream of the ATG start and downstream of the TGA stop codon, re spectively, and introduced specific artificial cloning sites: Xho I in the former case, Eco RI in the latter. The resulting PCR fragment of about 660 bp was purified digested with Xho I and Eco Rl, and subcloned into the corresponding polylinker restriction sites of Bluescript SK ${ }^{+}$. The pT $\alpha$ sequence between the $\mathrm{Nco}$ I site at the second in-frame ATG and the one Bgl II site downstream of the stop codons was replaced by the corresponding sequence from D2.1 in order to eliminate potential mutations introduced during the PCR amplification. The resulting plasmid was digested with Xho I and Not I to release the CDNA fragment encoding $\mathrm{pT} \alpha$, which was then inserted in the corresponding sites of expression vector BCMGSHyg (20). The construct was transfected into $58 \alpha^{-} \beta y .1$ cells by electroporation

44. We thank D. Avila, for microsequencing of the pTa protein; J. Kaufman, M. Reth, and J. Cébrian for help with the analysis of the pT $\alpha$ sequences C. Benoist, D. Mathis, and M. Wiles for advice on pT $\alpha$ cloning; J. Garcia-Sanz for advice on the RNA analysis; S. Goude, V. Stauffer, and C. Geiger for secretarial help; and $\mathrm{K}$. Hafen and $\mathrm{C}$. Laplace for expert technical assistance. The Basel Institute for Immunology is supported by Hoffmann-La Roche, Basel. Supported in part by the Institut National de la Santé and Recherche Medicale, Paris, and by the Faculté Necker Enfants Malades, Déscartes Université, Paris. H.v.B. is affiliated with the Faculté Necker, Paris, and also supported by the Human Frontier Science Project Organization (HFSPO).

9 September 1994; accepted 18 October 1994 


\section{Science}

\section{Analysis and expression of a cloned pre-T cell receptor gene}

C Saint-Ruf, K Ungewiss, M Groettrup, L Bruno, HJ Fehling and H von Boehmer

Science 266 (5188), 1208-1212.

DOI: $10.1126 /$ science. 7973703

ARTICLE TOOLS

REFERENCES

PERMISSIONS http://science.sciencemag.org/content/266/5188/1208

This article cites 36 articles, 9 of which you can access for free http://science.sciencemag.org/content/266/5188/1208\#BIBL

http://www.sciencemag.org/help/reprints-and-permissions 